\title{
Murine Double-Minute 2 Homolog Single Nucleotide Polymorphisms 285 and 309 in Cervical Carcinogenesis
}

\author{
Andrzej Roszak ${ }^{1,2} \cdot$ Matthew Misztal $^{3} \cdot$ Anna Sowińska $^{4} \cdot$ Pawel P. Jagodziński $^{3}$
}

Published online: 30 July 2015

(c) The Author(s) 2015. This article is published with open access at Springerlink.com

\begin{abstract}
Background and Objective In Caucasians, the MDM2 single nucleotide polymorphism (SNP) $285 \quad \mathrm{G}>\mathrm{C}$ (rs117039649) neutralizes the effect of $309 \quad \mathrm{~T}>\mathrm{G}$ (rs2279744), which increases MDM2 expression and impairs the p53 pathway. In this study, we examined the distribution of these two SNPs in Polish women with squamous cell carcinoma (SCC) $(n=379)$, adenocarcinoma $(n=59)$ and other cervical tumor types $(n=18)$.

Methods The polymerase chain reaction-restriction fragment length polymorphism technique and DNA sequencing were employed in our study.

Results The $P$ trend value calculated for the MDM2 285 $\mathrm{G}>\mathrm{C}$ polymorphism was statistically significant $\left(P_{\text {trend }}=0.016\right)$ for SCC. Using logistical regression analysis adjusted for the effect of age, pregnancy, oral contraceptive use, tobacco smoking, and menopausal status, we observed that the MDM2 $285 \mathrm{G}>\mathrm{C}$ SNP protected against SCC, with an adjusted odd ratio (OR) for the $\mathrm{C}$ carriers
\end{abstract}

Electronic supplementary material The online version of this article (doi:10.1007/s40291-015-0153-4) contains supplementary material, which is available to authorized users.

Pawel P. Jagodziński

pjagodzi@am.poznan.pl

1 Department of Radiotherapy and Gynecological Oncology, Greater Poland Cancer Center, Poznan, Poland

2 Department of Electroradiology, Poznan University of Medical Sciences, Poznan, Poland

3 Department of Biochemistry and Molecular Biology, Poznan University of Medical Sciences, 6 Święcickiego St., 60-781 Poznan, Poland

4 Department of Computer Science and Statistics, Poznan University of Medical Sciences, Poznan, Poland versus $\mathrm{G} / \mathrm{G}$ genotype of $0.536(P=0.019)$. Stratified analyses of MDM2 $285 \mathrm{G}>\mathrm{C}$ revealed a protective role of the $\mathrm{C}$ allele against SCC in women with a positive history of oral contraceptive use (age-adjusted OR 0.413, $P=0.021$ ) and in premenopausal women (age-adjusted OR 0.362 , $P=0.022$ ). We also found that the $285 \mathrm{GG} / 309 \mathrm{GG}$ vs $285 \mathrm{GG} / 309$ TT genotype increased the risk of SCC (adjusted OR 1.890, $P=0.005)$. However, the $285 \mathrm{CC} /$ $309 \mathrm{GG}+285 \mathrm{GC} / 309 \mathrm{GG}$ versus $285 \mathrm{GG} / 309 \mathrm{GG}$ genotype reduced the risk of SCC (adjusted OR 0.311, $P=0.004$ ). Conclusion Our results demonstrate that the MDM2 285C gene variant and $285 \mathrm{CC} / 309 \mathrm{GG}+285 \mathrm{GC} / 309 \mathrm{GG}$ genotypes protect against SCC, most likely by neutralizing the effect of the $309 \mathrm{~T}>\mathrm{G}$ SNP. The 285GG/309GG genotype increases the risk of SCC possibly due to increased MDM2 expression.

\section{Key Points}

The MDM2 $309 \mathrm{~T}>\mathrm{G}$ (rs2279744) single nucleotide polymorphism (SNP), causes increased $M D M 2$ expression whose action is neutralized by $285 \mathrm{G}>\mathrm{C}$ (rs117039649) SNP, located on 24 bps from SNP309 SNP.

Our genetic assessment demonstrated that the MDM2 $285 \mathrm{G}>\mathrm{C}$ polymorphism protects against squamous cell carcinoma (SCC), but the $309 \mathrm{~T}>\mathrm{G}$ does not have the same quality.

The combined 285CC/309GG $+285 \mathrm{GC} / 309 \mathrm{GG}$ genotypes protect against SCC, whereas the $285 \mathrm{GG} /$ 309GG genotype increases the risk of SCC in the Caucasian populations. 


\section{Introduction}

Cervical tumors are the third most frequent type of neoplasia that causes death among women worldwide [1]. The incidence of cervical neoplasia is especially high in developing countries, accounting for $86 \%$ of all newly diagnosed cases worldwide [1]. Infections with high-risk types of human papillomavirus (HR-HPV) are thought to be the main etiological agents of cervical lesions [2]. HPV infections have been identified in nearly $100 \%$ of all squamous cell carcinoma (SCC) cases [3], and it has been estimated that approximately 15-40 \% of sexually active women are infected with HR-HPV [4]. Despite the frequency of HPV infections, only a small percentage of these women exhibit persistent positivity for HR-HPV types [5]. Apart from HPV, other susceptibility variables of cervical lesions have been identified, including social status, tobacco consumption, multi-parity, oral contraceptive use, age of sexual debut, and environmental pollutants $[6,7]$. These data indicate that interactions between various susceptibility variables and genetic backgrounds are essential for the cancerous transformation of HR-HPV-infected cervical epithelial cells to cervical malignancies [6-9].

Expression of the HPV E6/E7 oncoproteins leads to the inactivation of tumor suppressor proteins p53 and retinoblastoma tumor suppressor protein (pRB), eventually causing uncontrolled cell cycle progression, increased cell survival, and accumulation of DNA damage [10, 11]. Murine double-minute 2 homolog (MDM2) is a major negative regulator of p53 protein levels $[12,13]$. Furthermore, MDM2 interacts with $\mathrm{pRB}$ and binds to the activation domain of the E2F1 transcription factor that inhibits pRB regulatory functions [10].

Abnormal MDM2 levels have been linked to an increase in genetic errors that account for the onset and development of various diseases, including cancer $[14,15]$. The $T>G$ transition (rs2279744) at position 309 in the first intron of $M D M 2$ in the promoter region causes up-regulation of both MDM2 mRNA and protein, leading to impairment of the p53 pathway [16]. In Caucasians, a second functional single nucleotide polymorphism (SNP), $285 \mathrm{G}>\mathrm{C}$ (rs117039649), has been identified in the promoter region located 24 bps from SNP309 [17, 18]. This second SNP neutralizes the effect of the $309 \mathrm{~T}>\mathrm{G}$ transition in $M D M 2$, resulting in decreased MDM2 transcription [18]. There have been controversial findings demonstrating that the 309 MDM2 SNP is a susceptibility factor for the development of cervical cancer in disparate ethnicities [19-23].

The purpose of this study was to investigate the distribution of MDM2 $309 \mathrm{~T}>\mathrm{G}$ and $285 \mathrm{G}>\mathrm{C}$ SNPs in women with squamous cell carcinoma (SCC) $(n=379)$, adenocarcinoma $(n=59)$ and other cervical tumor types $(n=18)$ and controls $(n=481)$ from a Polish population.

\section{Patients and Methods}

\subsection{Study Population}

The study population consisted of 456 patients with an assessed stage, histological grade and cervical tumor type based on the International Federation of Gynecology and Obstetrics. Patients' data were obtained from patients enrolled between July 2008 and August 2014 at the Department of Radiotherapy of the Greater Poland Cancer Center in Poznań, Poland. The patient group included randomly selected women with SCC $(n=379)$, adenocarcinoma $(n=59)$ or other histologic types of tumor $(n=18)$ (Table 1).

The control group consisted of 481 unrelated healthy female volunteers selected during medical examination at the University Hospital, Clinic of Gynecological Surgery at Poznań University of Medical Science (Table 1). Information regarding pregnancy, oral contraceptive use, tobacco smoking, and menopausal status was obtained as part of the patient history. All the patients and controls participating in the study were Caucasians from the Wielkopolska area of Poland. Informed consent was obtained from all participating individuals. The study methods were approved by the Local Ethical Committee of the Poznań University of Medical Sciences (reference number of ethical approval: 1010/07).

\subsection{Genotyping}

DNA was isolated from peripheral blood leucocytes using the salting out method. We initially sought to identify the MDM2 $309 \mathrm{~T}>\mathrm{G}$ (rs2279744) polymorphism by PCR using the primers $5^{\prime}$-GAGCGGTCACTTTTGGGTCT- $3^{\prime}$ and 5-CGGAACGTGTCTGAACTTGAC-3'. The PCR-amplified MDM2 fragment, which is $437 \mathrm{bp}$ in length, was digested using the endonuclease MspA1I (CMG/CKG; $\mathrm{M}=\mathrm{A}$ or $\mathrm{C} ; \mathrm{K}=\mathrm{G}$ or $\mathrm{T}$ ) (New England Biolabs, Ipswich, USA) according to the manufacturer's protocol. The MDM2 309G gene variant was cut into 244, 147 and $46 \mathrm{bp}$ fragments, while the MDM2 309T gene variant was cut into 244 and 193 bp fragments. DNA digestion products were separated by electrophoresis on a $3 \%$ agarose gel and visualized by ethidium bromide staining. Because we did not observe differences in the distribution of the MDM2 $309 \mathrm{~T}>\mathrm{G}$ polymorphism between cases and controls, we subsequently decided to determine the distribution of the 285G $>$ C (117039649) SNP. We found that only the FauI restriction enzyme could recognize the MDM2 $285 \mathrm{G}>\mathrm{C}$ (117039649) SNP, although this enzyme also recognized several other restriction sites inside the amplified fragment. Therefore, the presence of the MDM2 $285 \quad \mathrm{G}>\mathrm{C}$ 
Table 1 Clinical and demographic characteristics of patients and controls

\begin{tabular}{|c|c|c|}
\hline Characteristic & Patients $(n=456)$ & Controls $(n=481)$ \\
\hline Mean age (years) $\pm \mathrm{SD}^{\mathrm{a}}$ & $48.3 \pm 10.8$ & $47.8 \pm 9.5$ \\
\hline \multicolumn{3}{|l|}{ Tumor stage } \\
\hline IA & $62(13.6 \%)$ & \\
\hline IB & $63(13.8 \%)$ & \\
\hline IIA & $61(13.4 \%)$ & \\
\hline IIB & $57(12.5 \%)$ & \\
\hline IIIA & $145(31.8 \%)$ & \\
\hline IIIB & $53(11.6 \%)$ & \\
\hline IVA & $8(1.8 \%)$ & \\
\hline IVB & $7(1.5 \%)$ & \\
\hline \multicolumn{3}{|l|}{ Histological grade } \\
\hline G1 & $87(19.1 \%)$ & \\
\hline G2 & $146(32.0 \%)$ & \\
\hline G3 & $98(21.5 \%)$ & \\
\hline Gx & $125(27.4 \%)$ & \\
\hline \multicolumn{3}{|l|}{ Histological type } \\
\hline Squamous cell carcinoma & $379(83.1 \%)$ & \\
\hline Adenocarcinoma & $59(12.9 \%)$ & \\
\hline Other & $18(4.0 \%)$ & \\
\hline \multicolumn{3}{|l|}{ Pregnancy } \\
\hline Never & $51(11.2 \%)$ & $51(10.6 \%)$ \\
\hline Ever & $405(88.8 \%)$ & $430(89.4 \%)$ \\
\hline \multicolumn{3}{|l|}{ Oral contraceptive pill use } \\
\hline Never & $247(54.2 \%)$ & $269(55.9 \%)$ \\
\hline Ever & $209(45.8 \%)$ & $212(44.1 \%)$ \\
\hline \multicolumn{3}{|l|}{ Tobacco smoking } \\
\hline Never & $293(64.3 \%)$ & $334(69.4 \%)$ \\
\hline Ever & $163(35.7 \%)$ & $147(30.6 \%)$ \\
\hline \multicolumn{3}{|l|}{ Menopausal status } \\
\hline Premenopausal & $162(35.5 \%)$ & $179(37.2 \%)$ \\
\hline Postmenopausal & $294(64.5 \%)$ & $302(62.8 \%)$ \\
\hline \multicolumn{3}{|l|}{ HPV genotypes ${ }^{\mathrm{b}}$} \\
\hline 16 and 18 & $301(66.0 \%)$ & \\
\hline $16,18,31,33,35,39,45,51,52,56,58,59$ and 68 & $341(74.8 \%)$ & \\
\hline
\end{tabular}

${ }^{a}$ Age at first diagnosis

b HPV genotypes were determined by cobas ${ }^{\circledR}$ HPV Test Roche Molecular Systems, Inc., (Alameda, CA, USA) polymorphism was determined by Sanger sequencing analysis using the same pair of primers used for the MDM2 $309 \mathrm{~T}>\mathrm{G}$ SNP. The presence of the MDM2 $309 \mathrm{~T}>\mathrm{G}$ SNP was also verified by blindly selecting $30 \%$ of the samples for sequencing analysis.

\subsection{Statistical Evaluation}

The distinction in genotypic and allelic prevalence between the patients and controls and their genotype deviation from
Hardy-Weinberg (HW) equilibrium were evaluated using a $\chi^{2}$ test. The polymorphism was tested for association with cervical cancer incidence using the Cochran-Armitage $P$ trend test $\left(P_{\text {trend }}\right)$. The $\chi^{2}$ and Fisher exact tests were used to determine the differences in genotypic distributions between the patients and controls. The odds ratio (OR) and $95 \%$ confidence intervals $(95 \% \mathrm{CI}$ ) were also calculated. A logistic regression analysis was used to adjust for the effect of confounders such as age, pregnancy, oral contraceptive use, tobacco smoking, and menopausal status. A 
$P$ value of $<0.05$ was considered statistically significant. Statistical analyses were conducted using Statistica version 10, 2011 (Stat Soft, Inc., Tulsa, USA).

\section{Results}

\subsection{Distribution of the MDM2 $309 \mathrm{~T}>\mathrm{G}$ (rs2279744) Polymorphism Among Patients with Cervical Cancer and Controls}

The values for the $\chi^{2}$ test of HW equilibrium were 0.396 and 0.154 for the patients and controls, respectively. The distribution and statistical analyses of the MDM2 $309 \mathrm{~T}>\mathrm{G}$ genotype in the patients and controls are summarized in Table 2. For all patients with cervical cancer, the $P$ trend value calculated for the MDM2 $309 \mathrm{~T}>\mathrm{G}$ transition was not statistically significant $\left(P_{\text {trend }}=0.251\right)$. The logistic regression analysis, which adjusted for the effect of age, pregnancy, oral contraceptive use, tobacco smoking, and menopausal status, also did not demonstrate an association with the MDM2 $309 \mathrm{~T}>\mathrm{G}$ transition for the cervical cancer patients (Table 2). Furthermore, we did not observe an association of the MDM2 $309 \mathrm{~T}>\mathrm{G}$ polymorphism with histological type, SCC, adenocarcinoma, other tumors, histological grade or tumor stage (Table 2, Online Resource 1).

\subsection{Distribution of the MDM2 $285 \mathrm{G}>\mathrm{C}$ (rs117039649) Polymorphism Among Patients with Cervical Cancer and Controls}

The values for the $\chi^{2}$ test of HW equilibrium were 0.612 and 0.403 for the patients and controls, respectively. The prevalence and statistical analyses of the MDM2 $285 \mathrm{G}>\mathrm{C}$ genotypes in the patients and controls are presented in Table 3. For all patients with cervical cancer, the p-trend value calculated for the MDM2 $285 \mathrm{G}>\mathrm{C}$ polymorphism was statistically significant $\left(P_{\text {trend }}=0.008\right)$. Adjusting for the effect of age, pregnancy, oral contraceptive use, tobacco smoking, and menopausal status, the logistic regression analysis demonstrated that the $\mathrm{G} / \mathrm{C}$ versus $\mathrm{G} / \mathrm{G}$ genotype has a significant protective role in cervical carcinogenesis, with an adjusted OR $0.540 \quad(95 \%$ CI 0.326-0.896, $P=0.017$ ). There was also a protective effect of the $\mathrm{C} / \mathrm{C}$ and $\mathrm{G} / \mathrm{C}$ versus $\mathrm{G} / \mathrm{G}$ genotype, with an adjusted OR 0.523 (95\% CI 0.319-0.858, $P=0.010$ ).

There was also an association of the MDM2 $285 \mathrm{G}>\mathrm{C}$ SNP with SCC (Table 3). In patients with SCC, the p-trend value calculated for the MDM2 $285 \mathrm{G}>\mathrm{C}$ polymorphism was statistically significant $\left(P_{\text {trend }}=0.016\right)$. We observed a protective effect of the $\mathrm{C} / \mathrm{C}$ and $\mathrm{G} / \mathrm{C}$ versus $\mathrm{G} / \mathrm{G}$ genotype, with an adjusted OR 0.536 (95\% CI 0.317-0.905, $P=0.019)$. However, we did not observe an association of the MDM2 $285 \mathrm{G}>\mathrm{C}$ polymorphism with adenocarcinoma,

Table 2 Prevalence of the MDM2 309T>G (rs2279744) polymorphism among all patients with cervical cancer, SCC and and controls

\begin{tabular}{|c|c|c|c|c|c|c|c|}
\hline Genotype & $\begin{array}{l}\text { Patients (frequency } \\
\% \text { ) }\end{array}$ & $\begin{array}{l}\text { Controls (frequency } \\
\%)\end{array}$ & $\begin{array}{l}\text { Odds ratio }(95 \% \\
\text { CI) }\end{array}$ & $P^{\mathrm{a}}$ & $\begin{array}{l}\text { Adjusted odds ratio (95\% } \\
\text { CI) })^{\mathrm{b}}\end{array}$ & $P^{\mathrm{a}}$ & $P_{\text {trend }}$ \\
\hline \multicolumn{8}{|l|}{ All } \\
\hline $\mathrm{T} / \mathrm{T}$ & $174(38.2)$ & $202(42.0)$ & Referent & - & Referent & - & - \\
\hline $\mathrm{T} / \mathrm{G}$ & $204(44.7)$ & $204(42.4)$ & $1.161(0.877-1.537)$ & 0.297 & $1.174(0.885-1.588)$ & 0.265 & 0.251 \\
\hline $\mathrm{G} / \mathrm{G}$ & $78(17.1)$ & $75(15.6)$ & $1.207(0.829-1.759)$ & 0.326 & $1.099(0.910-1.328)$ & 0.326 & \\
\hline $\begin{array}{l}\mathrm{T} / \mathrm{G}+\mathrm{G} / \\
\mathrm{G}\end{array}$ & $282(61.8)$ & $279(58.0)$ & $1.173(0.903-1.525)$ & 0.231 & $1.180(0.907-1.535)$ & 0.217 & \\
\hline $\mathrm{MAF}^{\mathrm{c}}$ & 0.39 & 0.37 & & & & & \\
\hline \multicolumn{8}{|c|}{ Squamous cell carcinoma } \\
\hline $\mathrm{T} / \mathrm{T}$ & $139(36.7)$ & $202(42.0)$ & Referent & - & Referent & - & 0.086 \\
\hline $\mathrm{T} / \mathrm{G}$ & 169 (44.6) & $204(42.4)$ & $1.204(0.895-1.620)$ & 0.221 & $1.212(0.898-1.637)$ & 0.208 & \\
\hline $\mathrm{G} / \mathrm{G}$ & $71(18.7)$ & 75 (15.6) & $1.376(0.932-2.032)$ & 0.108 & $1.174(0.964-1.429)$ & 0.110 & \\
\hline $\begin{array}{l}\mathrm{T} / \mathrm{G}+\mathrm{G} / \\
\mathrm{G}\end{array}$ & $240(63.3)$ & $279(58.0)$ & $1.250(0.948-1.648)$ & 0.113 & $1.257(0.951-1.660)$ & 0.107 & \\
\hline $\mathrm{MAF}^{\mathrm{c}}$ & 0.41 & 0.37 & & & & & \\
\hline
\end{tabular}


Table 3 Prevalence of the MDM2 285 G>C (rs117039649) polymorphism among all patients with cervical cancer, SCC and controls

\begin{tabular}{|c|c|c|c|c|c|c|c|}
\hline Genotype & $\begin{array}{l}\text { Patients (frequency } \\
\%)\end{array}$ & $\begin{array}{l}\text { Controls (frequency } \\
\%)\end{array}$ & $\begin{array}{l}\text { Odds ratio }(95 \% \\
\text { CI })\end{array}$ & $P^{\mathrm{a}}$ & $\begin{array}{l}\text { Adjusted odds ratio (95\% } \\
\text { CI) }\end{array}$ & $P^{\mathrm{a}}$ & $P_{\text {trend }}$ \\
\hline \multicolumn{8}{|l|}{ All } \\
\hline $\mathrm{G} / \mathrm{G}$ & $430(94.3)$ & 431 (89.6) & Referent & - & Referent & - & 0.008 \\
\hline $\mathrm{G} / \mathrm{C}$ & $25(5.5)$ & $47(9.8)$ & $0.533(0.322-0.882)$ & 0.013 & $0.540(0.326-0.896)$ & 0.017 & \\
\hline $\mathrm{C} / \mathrm{C}$ & $1(0.2)$ & $3(0.6)$ & $0.334(0.035-3.226)$ & 0.624 & $0.536(0.171-1.688)$ & 0.286 & \\
\hline $\begin{array}{l}\mathrm{G} / \mathrm{C}+\mathrm{C} / \\
\mathrm{C}\end{array}$ & $26(5.7)$ & $50(10.4)$ & $0.521(0.319-0.853)$ & 0.009 & $0.523(0.319-0.858)$ & 0.010 & \\
\hline $\mathrm{MAF}^{\mathrm{c}}$ & 0.03 & 0.06 & & & & & \\
\hline \multicolumn{8}{|c|}{ Squamous cell carcinoma } \\
\hline $\mathrm{G} / \mathrm{G}$ & 357 (94.2) & $431(89.6)$ & Referent & - & Referent & - & 0.016 \\
\hline $\mathrm{G} / \mathrm{C}$ & $21(5.5)$ & $47(9.8)$ & $0.539(0.316-0.920)$ & 0.022 & $0.552(0.322-1.044)$ & 0.048 & \\
\hline $\mathrm{C} / \mathrm{C}$ & $1(0.3)$ & $3(0.6)$ & $0.402(0.042-3.888)$ & 0.631 & $0.563(0.176-1.799)$ & 0.332 & \\
\hline $\begin{array}{l}\mathrm{G} / \mathrm{C}+\mathrm{C} / \\
\mathrm{C}\end{array}$ & $22(5.8)$ & $50(10.4)$ & $0.531(0.316-0.894)$ & 0.016 & $0.536(0.317-0.905)$ & 0.019 & \\
\hline $\mathrm{MAF}^{\mathrm{c}}$ & 0.03 & 0.06 & & & & & \\
\hline
\end{tabular}

Significant results are highlighted in bold font

a $\chi^{2}$ or Fisher exact test

${ }^{\mathrm{b}}$ ORs were adjusted by age, pregnancy, oral contraceptive use, tobacco smoking, and menopausal status

${ }^{c}$ Minor allele frequency

other tumors, histological grade or tumor stage (Online Resource 2).

\subsection{Stratified Analyses Between the MDM2 $309 \mathrm{~T}>\mathrm{G}$ and MDM2 285 G $>C$ Genotypes and Cervical Cancer Risks}

Stratified analyses did not reveal any association of the MDM2 $309 \mathrm{~T}>\mathrm{G}$ genotypes with pregnancy, oral contraceptive use, tobacco smoking, or menopausal status in patient groups with SCC, adenocarcinoma, other tumors, different histological grades and tumor stage (data not shown).

In contrast, the stratified analysis for MDM2 $285 \mathrm{G}>\mathrm{C}$ revealed a protective role of this polymorphism among patients of all histological types with a positive history of pregnancy and oral contraceptive use and among women of premenopausal age (Table 4). The age-adjusted OR for women with a history of pregnancy possessing the $\mathrm{C}$ allele was 0.547 (95\% CI $0.318-0.881, P=0.034)$. The ageadjusted OR for women with a history of contraceptive use possessing the C allele was 0.541 (95 \% CI 0.223-0.901, $P=0.022)$. The age-adjusted OR for premenopausal women possessing the $\mathrm{C}$ allele was $0.362(95 \% \mathrm{CI}$ $0.151-0.956, P=0.018)$. However, no significant association was observed between MDM2 $285 \mathrm{G}>\mathrm{C}$ and patients with a positive history of tobacco smoking.

We also found a protective role of the $\mathrm{C}$ allele against $\mathrm{SCC}$ in women with a positive history of oral contraceptive use (age-adjusted OR 0.413; $95 \%$ CI $0.191-0.985$, $P=0.021$ ) and in premenopausal women (age-adjusted OR $0.362 ; 95 \%$ CI $0.137-0.928, P=0.022$ ) (Table 5). However, we did not observe an association between MDM2 $285 \mathrm{G}>\mathrm{C}$ SNP and pregnancy, oral contraceptive use, tobacco smoking, or menopausal status in patients with adenocarcinoma and other tumors (data not shown). Moreover, there was no association of either the MDM2 $285 \mathrm{G}>\mathrm{C}$ or $309 \mathrm{~T}>\mathrm{G}$ polymorphism with HPV genotypes (data not shown).

\subsection{Distribution of the MDM2 $285 \mathrm{G}>\mathrm{C}$ and 309 T>G Combined Genotypes Among Patients with Cervical Cancer and Controls}

The distribution and logistic regression analyses of the MDM2 $285 \mathrm{G}>\mathrm{C}$ and $309 \mathrm{~T}>\mathrm{G}$ combined genotypes in the patients and controls are presented in Table 6. Adjusting for the effect of age, pregnancy, oral contraceptive use, tobacco smoking, and menopausal status, the logistic regression analysis demonstrated that the $285 \mathrm{GG} / 309 \mathrm{GG}$ versus the 285GG/309 TT genotypes are significantly associated with all histological types of cervical cancer, with an adjusted OR 1.753 (95\% CI 1.136-2.703, $P=0.011$ ) (Table 6). Moreover, for all patients with cervical cancer, we observed a protective effect of the $285 \mathrm{CC} /$ $309 \mathrm{GG}+285 \mathrm{GC} / 309 \mathrm{GG}$ versus the $285 \mathrm{GG} / 309 \mathrm{GG}$ genotypes, with an adjusted OR $0.306 \quad(95 \%$ CI 0.142-0.660, $P=0.002$ ) (Table 6). 
Table 4 Stratified analyses between the distribution of the MDM2 285G>C (rs117039649) genotypes and all histological types of cervical cancer risks: pregnancy, oral contraceptive use, tobacco smoking, and menopausal status

\begin{tabular}{|c|c|c|c|c|c|c|c|c|}
\hline \multirow{2}{*}{$\begin{array}{l}\text { High risk exposure } \\
\text { Genotype }\end{array}$} & \multicolumn{3}{|c|}{ Patients } & \multicolumn{3}{|c|}{ Controls } & \multirow[t]{2}{*}{ Adjusted allelic odds ratio $(95 \% \mathrm{CI})^{\mathrm{a}}$} & \multirow[t]{2}{*}{$P^{\mathrm{b}}$} \\
\hline & G/G & $\mathrm{G} / \mathrm{C}$ & $\mathrm{C} / \mathrm{C}$ & G/G & $\mathrm{G} / \mathrm{C}$ & $\mathrm{C} / \mathrm{C}$ & & \\
\hline \multicolumn{9}{|l|}{ Pregnancy } \\
\hline Ever & 383 & 22 & 0 & 387 & 42 & 1 & $0.547(0.318-0.881)$ & $\mathbf{0 . 0 3 4}$ \\
\hline Never & 47 & 3 & 1 & 44 & 5 & 2 & $0.574(0.191-1.757)$ & 0.518 \\
\hline \multicolumn{9}{|c|}{ Oral contraceptive use } \\
\hline Ever & 198 & 11 & 0 & 189 & 21 & 2 & $0.541(0.223-0.901)$ & 0.022 \\
\hline Never & 232 & 14 & 1 & 242 & 26 & 1 & $0.671(0.367-1.161)$ & 0.161 \\
\hline \multicolumn{9}{|l|}{ Smoking } \\
\hline Ever & 155 & 8 & 0 & 133 & 12 & 2 & $0.464(0.196-1.068)$ & 0.066 \\
\hline Never & 275 & 17 & 1 & 298 & 35 & 1 & $0.583(0.364-0.995)$ & 0.061 \\
\hline \multicolumn{9}{|l|}{ Menopausal status } \\
\hline Premenopausal & 155 & 7 & 0 & 160 & 17 & 2 & $0.363(0.151-0.956)$ & 0.018 \\
\hline Postmenopausal & 275 & 18 & 1 & 271 & 30 & 1 & $0.659(0.369-1.216)$ & 0.237 \\
\hline
\end{tabular}

Significant results are highlighted in bold font

a Odds Ratio were adjusted by age

b Chi square analysis

Table 5 Stratified analyses between the distribution of the $M D M 2$ 285G $>C$ (rs117039649) genotypes and squamous cell carcinoma risk: pregnancy, oral contraceptive use, tobacco smoking, and menopausal status

\begin{tabular}{|c|c|c|c|c|c|c|c|c|}
\hline \multirow{2}{*}{$\begin{array}{l}\text { High risk exposure } \\
\text { Genotype }\end{array}$} & \multicolumn{3}{|c|}{ Patients } & \multicolumn{3}{|c|}{ Controls } & \multirow[t]{2}{*}{ Adjusted allelic odds ratio $(95 \% \mathrm{CI})^{\mathrm{a}}$} & \multirow[t]{2}{*}{$P^{\mathrm{b}}$} \\
\hline & $\mathrm{G} / \mathrm{G}$ & $\mathrm{G} / \mathrm{C}$ & $\mathrm{C} / \mathrm{C}$ & $\mathrm{G} / \mathrm{G}$ & $\mathrm{G} / \mathrm{C}$ & $\mathrm{C} / \mathrm{C}$ & & \\
\hline \multicolumn{9}{|l|}{ Pregnancy } \\
\hline Ever & 318 & 20 & 0 & 387 & 42 & 1 & $0.584(0.361-0.988)$ & 0.052 \\
\hline Never & 39 & 1 & 1 & 44 & 5 & 2 & $0.401(0.124-1.461)$ & 0.273 \\
\hline \multicolumn{9}{|c|}{ Oral contraceptive use } \\
\hline Ever & 174 & 9 & 0 & 189 & 21 & 2 & $0.413(0.191-0.985)$ & 0.021 \\
\hline Never & 183 & 12 & 1 & 242 & 26 & 1 & $0.784(0.372-1.257)$ & 0.287 \\
\hline \multicolumn{9}{|l|}{ Smoking } \\
\hline Ever & 138 & 7 & 0 & 133 & 12 & 2 & $0.441(0.191-1.121)$ & 0.071 \\
\hline Never & 219 & 14 & 1 & 298 & 35 & 1 & $0.713(0.345-1.122)$ & 0.109 \\
\hline \multicolumn{9}{|l|}{ Menopausal status } \\
\hline Premenopausal & 126 & 5 & 0 & 160 & 17 & 2 & $0.362(0.137-0.928)$ & 0.022 \\
\hline Postmenopausal & 231 & 16 & 1 & 271 & 30 & 1 & $0.696(0.383-1.274)$ & 0.201 \\
\hline
\end{tabular}

Significant results are highlighted in bold font

a Odds Ratio were adjusted by age

${ }^{\mathrm{b}}$ Chi square analysis

The reanalysis based on the histological type demonstrated that the $285 \mathrm{GG} / 309 \mathrm{GG}$ versus the $285 \mathrm{GG} / 309 \mathrm{TT}$ genotype is a significant risk factor for SCC with an adjusted OR $1.890(95 \%$ CI $1.208-2.957, P=0.005)$ (Table 6). There was also a protective role of the $285 \mathrm{CC} /$ $309 \mathrm{GG}+285 \mathrm{GC} / 309 \mathrm{GG}$ versus the $285 \mathrm{GG} / 309 \mathrm{GG}$ genotype in SCC with an adjusted OR 0.311 (95\% CI $0.141-0,689, P=0.004)$. There was no association between the MDM2 $285 \mathrm{G}>\mathrm{C}$ and $309 \mathrm{~T}>\mathrm{G}$ combined genotypes with adenocarcinoma, other tumors, histological grade or tumor stage (Online Resource 3).

\section{Discussion}

MDM2 is considered an oncogene whose overexpression results in malignant transformations. The overexpression of $M D M 2$ has been observed in various human malignancies, 
Table 6 Prevalence of the MDM2 285G $>\mathrm{C}$ and 309T $>\mathrm{G}$ combined genotypes

\begin{tabular}{|c|c|c|c|c|}
\hline $\begin{array}{l}\text { SNP 285/309 MDM2 } \\
\text { genotype }\end{array}$ & $\begin{array}{l}\text { Patients (frequency } \\
\% \text { ) }\end{array}$ & $\begin{array}{l}\text { Controls (frequency } \\
\%)\end{array}$ & Odds ratio $(95 \% \mathrm{CI}), P^{\mathrm{a}}$ & $\begin{array}{l}\text { Adjusted odds ratio }(95 \% \mathrm{CI})^{\mathrm{d}} \text {, } \\
P^{\mathrm{a}}\end{array}$ \\
\hline \multicolumn{5}{|l|}{ All } \\
\hline GG/TT & $174(38.2)$ & $202(42.0)$ & Referent & Referent \\
\hline GG/TG & $191(41.9)$ & $184(38.3)$ & $\begin{array}{l}1.205(0.905-1.605), \\
0.202\end{array}$ & $1.296(0.972-1.726), 0.076$ \\
\hline GC/TG & $13(2.9)$ & $20(4.2)$ & $\begin{array}{l}0.755(0.365-1.562) \\
0.447\end{array}$ & $0.834(0.399-1.740), 0.627$ \\
\hline GG/GG & $65(14.3)$ & $45(9.4)$ & $\begin{array}{l}1.677(1.090-2.580), \\
0.018\end{array}$ & 1.753 (1.136-2.703), 0.011 \\
\hline GC/GG & $12(2.6)$ & $27(5.6)$ & \multirow{2}{*}{$\begin{array}{l}0.503(0.254-0.995) \\
0.045^{\mathrm{b}}\end{array}$} & \multirow[t]{2}{*}{$0.438(0.043-4.464), 0.485$} \\
\hline $\mathrm{CC} / \mathrm{GG}$ & $1(0.2)$ & $3(0.6)$ & & \\
\hline $\mathrm{GC} / \mathrm{TG}+(\mathrm{GC}+\mathrm{CC}) / \mathrm{GG}$ & $26(5.7)$ & $50(10.4)$ & $\begin{array}{l}0.604(0.361-1.011) \\
0.053^{\mathrm{c}}\end{array}$ & $0.628(0.373-1.059), 0.081$ \\
\hline $\begin{array}{l}\mathrm{CC} / \mathrm{GG}+\mathrm{GC} / \mathrm{GG} \text { vs GG/ } \\
\mathrm{GG}\end{array}$ & $13(2.9)$ vs 65 (14.3) & $30(6.2)$ vs $45(9.4)$ & $\begin{array}{l}0.300(0.141-0.638), \\
0.001\end{array}$ & $0.306(0.142-0.660), 0.002$ \\
\hline GC/TG vs GG/TG & 13 (2.9) vs 191 (41.9) & $20(4.2)$ vs $184(38.3)$ & $\begin{array}{l}0.626(0.303-1.296) \\
0.204\end{array}$ & $0.632(0.304-1.316), 0.219$ \\
\hline \multicolumn{5}{|l|}{ Squamous cell carcinoma } \\
\hline GG/TT & $139(36.7)$ & $202(42.0)$ & Referent & Referent \\
\hline GG/TG & $159(41.9)$ & $184(38.3)$ & $\begin{array}{l}1.256(0.928-1.700) \\
0.140\end{array}$ & $1.262(0.930-1.714), 0.135$ \\
\hline GC/TG & $10(2.6)$ & $20(4.2)$ & $\begin{array}{l}0.727(0.330-1.600) \\
0.426\end{array}$ & $0.739(0.333-1.641), 0.455$ \\
\hline GG/GG & $59(15.6)$ & $45(9.4)$ & $\begin{array}{l}1.905(1.222-2.971), \\
0.004\end{array}$ & 1.890 (1.208-2.957), 0.005 \\
\hline GC/GG & $11(2.9)$ & $27(5.6)$ & \multirow{2}{*}{$\begin{array}{l}0.581(0.288-1.175) \\
0.127\end{array}$} & \multirow[t]{2}{*}{$0.573(0.280-1.171), 0.125$} \\
\hline $\mathrm{CC} / \mathrm{GG}$ & $1(0.3)$ & $3(0.6)$ & & \\
\hline $\mathrm{GC} / \mathrm{TG}+(\mathrm{GC}+\mathrm{CC}) / \mathrm{GG}$ & $22(5.8)$ & $50(10.4)$ & $\begin{array}{l}0.639(0.370-1.104) \\
0.107^{\mathrm{c}}\end{array}$ & 0.643 (0.370-1.118), 0.116 \\
\hline $\begin{array}{l}\mathrm{CC} / \mathrm{GG}+\mathrm{GC} / \mathrm{GG} \text { vs GG/ } \\
\mathrm{GG}\end{array}$ & $12(3.2)$ vs 59 (15.6) & $30(6.2)$ vs $45(9.4)$ & $\begin{array}{l}0.305(0.141-0.662) \\
0.002\end{array}$ & $0.311(0.141-0.689), 0.004$ \\
\hline GC/TG vs GG/TG & $10(2.6)$ vs 159 (41.9) & $20(4.2)$ vs $184(38.3)$ & $\begin{array}{l}0.579(0.263-1.273) \\
0.169\end{array}$ & $0.578(0.261-1.283), 0.177$ \\
\hline
\end{tabular}

Significant results are highlighted in bold font

a $\chi^{2}$ test

b $(\mathrm{GC} / \mathrm{GG}+\mathrm{CC} / \mathrm{GG}$ vs GG/TT)

c $(\mathrm{GC} / \mathrm{TG}+\mathrm{GC} / \mathrm{GG}+\mathrm{CC} / \mathrm{GG}$ vs GG/TT)

${ }^{\mathrm{d}}$ ORs were adjusted by age, pregnancy, oral contraceptive use, tobacco smoking, and menopausal status

including sarcoma, melanoma, breast carcinoma, glioblastoma leukemia and others [24]. Studies conducted in animal models and in cells in vitro have demonstrated that MDM2 also displays p53-independent oncogenic properties that regulate proliferation, apoptosis, tumor invasion and metastasis [25-29]. MDM2 protein levels and function are precisely controlled at the transcriptional, translational [30-33] and post-translational levels [34-40]. Therefore, various SNPs occurring in the MDM2 gene could potentially dysregulated both transcription and translation.

The MDM2 $309 \mathrm{~T}>\mathrm{G}$ SNP augments the binding of transcriptional factor $\mathrm{Sp} 1$ to the $309 \mathrm{G}$ allele. This transition increases MDM2 protein levels by 2- to 4-fold and reduces p53 function [16].

In our study, we did not find a significant association between cervical cancer development or clinicopathological features and the MDM2 $309 \mathrm{~T}>\mathrm{G}$ SNP in our sample of the Polish population. Previous studies have shown that the MDM2 $309 \mathrm{~T}>\mathrm{G}$ polymorphism is not a risk factor for cervical cancer in northeastern Brazilian, Caucasian or African-American ethnicities [19, 20]. However, the MDM2 309 polymorphism has been shown to contribute to high-grade squamous intraepithelial lesions and HR-HPVrelated cervical carcinogenesis in a Japanese population 
[21]. Singhal et al. (2013) found that the MDM2 309 SNP in an Indian population is associated with cervical neoplasia, HPV infection and age at the time of neoplasia diagnosis [41]. Amaral et al. (2014) suggested MDM2 309 as a marker for the progression from low to high squamous intraepithelial lesions in a northeastern Brazilian population. This group also demonstrated that oral contraceptives, HPV infections and the MDM2 309 SNP synergistically contributed to cervical lesions [42]. The MDM2 309 SNP has also been shown to be a biomarker of cervical neoplasia in non-smoking women and in those with a family history of cancer in a southeastern Brazilian population [43]. A recently published meta-analysis did not demonstrate a significant association of the MDM2 309 SNP with cervical cancer risk in the overall population. However, a stratification-based ethnicity study revealed that the MDM2 309 SNP is a significant risk factor for cervical cancer in Asian populations [22].

Our results demonstrate that the $M D M 2285 \mathrm{G}>\mathrm{C}$ polymorphism may protect against SCC development in a sample of the Polish population.

The MDM2 $285 \mathrm{G}>\mathrm{C}$ polymorphism exists in complete linkage disequilibrium with MDM2 $309 \quad \mathrm{~T}>\mathrm{G}$ [17]. Knappskog et al. (2011) demonstrated that the $285 \mathrm{G}>\mathrm{C}$ SNP in the MDM2 promoter region did not exist in Asian populations but is present in Caucasian populations with an allele frequency of approximately $8 \%$ [18]. Moreover, they found that the $285 \mathrm{C} / 309 \mathrm{G}$ haplotype reduces the binding of Sp1 to the MDM2 promoter region and contributes to a reduced risk for breast and ovarian carcinomas in Caucasian populations [18]. Employing a plasmon resonance assay, Knappskog et al. (2011) demonstrated that the MDM2 309G allele increased the strength of binding to Sp1 by $22 \%$ compared to that observed with the MDM2 309T allele [18]. Additionally, the MDM2 285C allele led to a $51 \%$ decrease in the binding of Sp1 to the promoter region [18]. They showed that the MDM2 285C/309G haplotype, which is found in approximately $12 \%$ of all MDM2 309G alleles in Caucasians, displayed approximately $10 \%$ lower binding affinity to Sp1 than the MDM2 285G/309T haplotype. They also demonstrated that the MDM2 285G/309G haplotype exhibits the strongest binding between $\mathrm{Sp} 1$ and the MDM2 promoter region [44] and is likely responsible for the highest transcription rate of MDM2. These findings may partially explain the results of our study demonstrating that patients possessing the 285GG/309GG combined genotype exhibit an increased risk of SCC development. Moreover, the work of Knappskog et al. [18] is in agreement with our findings that indicate a protective role of the $285 \mathrm{CC} / 309 \mathrm{GG}+285 \mathrm{GC} /$ 309GG combined genotype against the development of SCC.
Our study also demonstrated that the MDM2 $285 \mathrm{G}>\mathrm{C}$ polymorphism may protect women who have used oral contraceptives and women of premenopausal age from SCC. These results are in agreement with previously published data suggesting a possible causative role of contraceptive use and menopausal status in cervical cancer development $[6,7]$ as well as a protective role of the MDM2 285G $>$ C SNP in some female estrogen-related cancers $[17,18]$. Oral contraceptives are used by premenopausal women and may affect the increase in MDM2 expression, which can be further reduced by the MDM2 $285 \mathrm{C}$ gene variant. It is notable that transcription factor Sp1 binds cooperatively with an estrogen receptor, and the $285 \mathrm{G}>\mathrm{C}$ transition is situated within the estrogen receptor binding site $[45,46]$. It should also be noted that cervical cancer has also been recognized as an estrogen-affected malignancy $[47,48]$.

Moreover, Renaux-Petel et al. (2014) recently found that Li-Fraumeni syndrome patients possessing the $285 \mathrm{G} / 309 \mathrm{G}$ haplotype display an onset of tumors 5 years earlier compared to patients possessing other haplotypes [49].

Our genetic assessment is the first to demonstrate that the MDM2 $285 \mathrm{G}>\mathrm{C}$ polymorphism and the $285 \mathrm{CC} /$ $309 \mathrm{GG}+285 \mathrm{GC} / 309 \mathrm{GG}$ combined genotype may protect against SCC and that the $285 \mathrm{GG} / 309 \mathrm{GG}$ combined genotype may increase the risk of SCC in Caucasian populations. However, this study is characterized by low statistical power for using these gene variants as a major predictor factor of cervical cancer development in clinical practice. Therefore, this study should be replicated in other larger independent cohorts.

Acknowledgments We gratefully acknowledge the technical assistance of Ms. Agnieszka Mikuczewska.

\section{Compliance with Ethical Standards}

Conflict of interest RA, MM, SA and JPP have no conflict of interest to report.

Funding This study, presented by RA, MM, SA and JPP, was funded by Grant No. 502-01-01124182-07474 from Poznan University of Medical Sciences.

Ethical Approval and Informed Consent The study procedures were approved by the local Ethical Committee of the Poznan University of Medical Sciences. Informed consent was obtained from all participating individuals.

Open Access This article is distributed under the terms of the Creative Commons Attribution-NonCommercial 4.0 International License (http://creativecommons.org/licenses/by-nc/4.0/), which permits any noncommercial use, distribution, and reproduction in any medium, provided you give appropriate credit to the original author(s) and the source, provide a link to the Creative Commons license, and indicate if changes were made. 


\section{References}

1. Jemal ADVM, Bray F, Center MM, Ferley J, Ward E, Forman D. Global cancer statistic. CA Cancer J Clin. 2011;61:69-90.

2. Zur Hausen H. Papillomavirus infections-a major cause of human cancers. Biochim Biophys Acta. 1996;1288:F55-78.

3. Walboomers JM, Jacobs MV, Manos MM, Bosch FX, Kummer JA, Shah KV, Snijders PJ, Peto J, Meijer CJ, Muñoz N. Human papillomavirus is a necessary cause of invasive cervical cancer worldwide. J Pathol. 1999;189:12-9.

4. Villa LL. Human papillomaviruses and cervical cancer. Adv Cancer Res. 1997;71:321-41.

5. de Freitas AC, Gurgel AP, Chagas BS, Coimbra EC, do Amaral CM. Susceptibility to cervical cancer: an overview. Gynecol Oncol. 2012;126:304-11.

6. Castellsague X, Munoz N. Cofactors in human papillomavirus carcinogenesis - role of parity, oral contraceptives, and tobacco smoking, Chapter 3. J Natl Cancer Inst Monogr. 2003;20-8.

7. Moreno V, Bosch FX, Muñoz N, Meijer CJ, Shah KV, Walboomers JM, et al. Effect of oral contraceptives on risk of cervical cancer in women with human papillomavirus infection: the IARC multicentric case-control study. Lancet. 2002;359:1085-92.

8. Magnusson PK, Lichtenstein P, Gyllensten UB. Heritability of cervical tumours. Int J Cancer. 2000;88:698-701.

9. Wei L, Griego AM, Chu M, Ozbun MA. Tobacco exposure results in increased E6 and E7 oncogene expression, DNA damage and mutation rates in cells maintaining episomal human papillomavirus 16 genomes. Carcinogenesis. 2014;35:2373-81.

10. Münger K, Howley PM. Human papillomavirus immortalization and transformation functions. Virus Res. 2002;89:213-28.

11. Williams VM, Filippova M, Filippov V, Payne KJ, DuerksenHughes P. Human papillomavirus type 16 E6* induces oxidative stress and DNA damage. J Virol. 2014;88:6751-61.

12. Momand J, Zambetti GP, Olson DC, George D, Levine AJ. The mdm-2 oncogene product forms a complex with the p53 protein and inhibits p53-mediated transactivation. Cell. 1992;69:1237-45.

13. Oliner JD, Kinzler KW, Meltzer PS, George DL, Vogelstein B. Amplification of a gene encoding a p53-associated protein in human sarcomas. Nature. 1992;358:80-3.

14. Zhao Y, Yu H, Hu W. The regulation of MDM2 oncogene and its impact on human cancers. Acta Biochim Biophys Sin (Shanghai). 2014;46:180-9.

15. Eischen CM, Lozano G. The Mdm network and its regulation of $\mathrm{p} 53$ activities: a rheostat of cancer risk. Hum Mutat. 2014;35:728-37.

16. Bond GL, Hu W, Bond EE, Robins H, Lutzker SG, Arva NC, et al. A single nucleotide polymorphism in the MDM2 promoter attenuates the p53 tumor suppressor pathway and accelerates tumor formation in humans. Cell. 2004;119:591-602.

17. Paulin FE, O'Neill M, McGregor G, Cassidy A, Ashfield A, Ali CW, et al. MDM2 SNP309 is associated with high grade node positive breast tumours and is in linkage disequilibrium with a novel MDM2 intron 1 polymorphism. BMC Cancer. 2008;8:281.

18. Knappskog S, Bjornslett M, Myklebust LM, Huijts PE, Vreeswijk MP, Edvardsen H, et al. The MDM2 Promoter SNP285C/309G Haplotype Diminishes Sp1 Transcription Factor Binding and Reduces Risk for Breast and Ovarian Cancer in Caucasians. Cancer Cell. 2011;19:273-82.

19. Meissner Rde V, Barbosa RN, Fernandes JV, Galvão TM, Galvão AF, Oliveira GH. No association between SNP309 promoter polymorphism in the MDM2 and cervical cancer in a study from northeastern Brazil. Cancer Detect Prev. 2007;31:371-4.

20. Hu X, Zhang Z, Ma D, Huettner PC, Massad LS, Nguyen L, et al. TP53, MDM2, NQO1, and susceptibility to cervical cancer. Cancer Epidemiol Biomarkers Prev. 2010;19:755-61.
21. Nunobiki O, Ueda M, Yamamoto M, Toji E, Sato N, Izuma S, et al. MDM2 SNP 309 human papillomavirus infection in cervical carcinogenesis. Gynecol Oncol. 2010;118:258-61.

22. Zhuo X, Ren J, Li D, Wu Y, Zhou Q. MDM2 SNP309 variation increases cervical cancer risk among Asians. Tumour Biol. 2014;35:5331-7.

23. Knappskog S, Lønning PE. MDM2 SNP309 and risk of cervical cancer. Tumour Biol. 2014;35:6185-6.

24. Momand J, Jung D, Wilczynski S, Niland J. The MDM2 gene amplification database. Nucleic Acids Res. 1998;26:3453-9.

25. Xiao ZX, Chen J, Levine AJ, Modjtahedi N, Xing J, Sellers WR, et al. Interaction between the retinoblastoma protein and the oncoprotein MDM2. Nature. 1995;375:694-8.

26. Yang JY, Zong CS, Xia W, Yamaguchi H, Ding Q, Xie X, et al. ERK promotes tumorigenesis by inhibiting FOXO3a via MDM2mediated degradation. Nat Cell Biol. 2008;10:138-48.

27. Fu W, Ma Q, Chen L, Li P, Zhang M, Ramamoorthy S, et al. MDM2 acts downstream of p53 as an E3 ligase to promote FOXO ubiquitination and degradation. J Biol Chem. 2009;284:13987-4000.

28. Yang JY, Zong CS, Xia W, Wei Y, Ali-Seyed M, Li Z, et al. MDM2 promotes cell motility and invasiveness by regulating E-cadherin degradation. Mol Cell Biol. 2006;26:7269-82.

29. Huart AS, MacLaine NJ, Meek DW, Hupp TR. CK b1alpha plays a central role in mediating MDM2 control of p53 and E2F-1 protein stability. J Biol Chem. 2009;284:32384-94.

30. Mendrysa SM, Perry ME. The p53 tumor suppressor protein does not regulate expression of its own inhibitor, MDM2, except under conditions of stress. Mol Cell Biol. 2000;20:2023-30.

31. Zhang J, Sun Q, Zhang Z, Ge S, Han ZG, Chen WT. Loss of microRNA-143/145 disturbs cellular growth and apoptosis of human epithelial cancers by impairing the MDM2-p53 feedback loop. Oncogene. 2013;32:61-9.

32. Suh SS, Yoo JY, Nuovo GJ, Jeon YJ, Kim S, Lee TJ, et al. MicroRNAs/TP53 feedback circuitry in glioblastoma multiforme. Proc Natl Acad Sci USA. 2012;109:5316-21.

33. Xiao J, Lin H, Luo X, Wang Z. miR-605 joins p53 network to form a p53:miR-605:mdm2 positive feedback loop in response to stress. EMBO J. 2011;30:524-32.

34. Maya R, Balass M, Kim ST, Shkedy D, Leal JF, Shifman O, et al. ATM-dependent phosphorylation of Mdm2 on serine 395: role in p53 activation by DNA damage. Genes Dev. 2001;15:1067-77.

35. Tibbetts RS, Brumbaugh KM, Williams JM, Sarkaria JN, Cliby WA, Shieh SY, et al. A role for ATR in the DNA damageinduced phosphorylation of p53. Genes Dev. 1999;13:152-7.

36. Chen L, Li Z, Lane WS, Chen J, Shinozaki T, Nota A, et al. Functional role of Mdm2 phosphorylation by ATR in attenuation of p53 nuclear export. Oncogene. 2003;22:8870-80.

37. Lohrum MA, Ashcroft M, Kubbutat MH, Vousden KH. ATM activates p53 by regulating MDM2 oligomerization and E3 processivity. EMBO J. 2009;28:3857-67.

38. Ashcroft M, Kubbutat $\mathrm{MH}$, Vousden KH. Identification of a cryptic nucleolar-localization signal in MDM2. Nat Cell Biol. 2000;2:179-81.

39. Gajjar M, Candeias MM, Malbert-Colas L, Mazars A, Fujita J, Olivares-Illana $\mathrm{V}$, et al. The p53 mRNA-Mdm2 interaction controls Mdm2 nuclear trafficking and is required for p53 activation following DNA damage. Cancer Cell. 2012;21:25-35.

40. Goldberg Z, Vogt Sionov R, Berger M, Zwang Y, Perets R, Van Etten RA, et al. Tyrosine phosphorylation of Mdm2 by c-Abl: implications for p53 regulation. EMBO J. 2002;21:3715-27.

41. Singhal $P$, Hussain $S$, Thakur N, Batra S, Salhan S, Bhambani S, et al. Association of MDM2 and p53 polymorphisms with the advancement of cervical carcinoma. DNA Cell Biol. 2013;32:19-27. 
42. Amaral CM, Cetkovská K, Gurgel AP, Cardoso MV, Chagas BS, Paiva Júnior SS, et al. MDM2 polymorphism associated with the development of cervical lesions in women infected with Human papillomavirus and using of oral contraceptives. Infect Agent Cancer. 2014;9:24.

43. Vargas-Torres SL, Portari EA, Klumb EM, Guillobel HC, Camargo MJ, Russomano FB, et al. Effects of MDM2 promoter polymorphisms on the development of cervical neoplasia in a Southeastern Brazilian population. Biomarkers. 2014;19:637-45.

44. Knappskog S, Lønning PE. Effects of the MDM2 promoter SNP285 and SNP309 on Sp1 transcription factor binding and cancer risk. Transcription. 2011;2:207-10.

45. Neo SJ, Su X, Thomsen JS. Surface plasmon resonance study of cooperative interactions of estrogen receptor alpha and transcriptional factor Sp1 with composite DNA elements. Anal Chem. 2009;81:3344-9.
46. Knappskog S, Trovik J, Marcickiewicz J, Tingulstad S, Staff AC, MoMaTEC study group, et al. SNP285C modulates oestrogen receptor/Sp1 binding to the MDM2 promoter and reduces the risk of endometrial but not prostatic cancer. Eur $\mathrm{J}$ Cancer. 2012;48:1988-96.

47. Son J, Park JW, Lambert PF, Chung SH. Requirement of estrogen receptor alpha DNA-binding domain for HPV oncogene-induced cervical carcinogenesis in mice. Carcinogenesis. 2014;35:489-96.

48. Cortés-Malagón EM, Bonilla-Delgado J, Díaz-Chávez J, Hidalgo-Miranda A, Romero-Cordoba S, Uren A, et al. Gene expression profile regulated by the HPV16 E7 oncoprotein and estradiol in cervical tissue. Virology. 2013;447:155-65.

49. Renaux-Petel M, Sesboüé R, Baert-Desurmont S, Vasseur S, Fourneaux S, Bessenay E, et al. The MDM2 285G-309G haplotype is associated with an earlier age of tumour onset in patients with Li-Fraumeni syndrome. Fam Cancer. 2014;13:127-30. 